\title{
Neuroendocrine Regulation of Metabolism
}

\author{
M. P. Cornejo*, S. T. Hentges $\uparrow$, M. Maliqueot, H. Coirini§, D. Becu-Villalobos $\uparrow$ and C. F. Elias** \\ * Laboratory of Neurophysiology, Multidisciplinary Institute of Cell Biology [IMBICE, dependent on the Argentine Research Council (CONICET), Scientific \\ Research Commission, Province of Buenos Aires (CIC-PBA) and National University of La Plata (UNLP)], La Plata, Argentina. \\ $\dagger$ Department of Biomedical Sciences, Colorado State University, Fort Collins, CO, USA. \\ $\$$ Endocrinology and Metabolism Laboratory, Department of Medicine West Division, School of Medicine University of Chile, Santiago de Chile, Chile. \\ §Laboratory of Neurobiology, Institute of Biology and Experimental Medicine [(IBYME), dependent on CONICET] and Department of Human Biochemistry, \\ University of Buenos Aires, Buenos Aires, Argentina. \\ - Laboratory of Pituitary Regulation, Institute of Biology and Experimental Medicine [(IBYME), dependent on CONICET], Buenos Aires, Argentina. \\ ** Molecular and Integrative Physiology, University of Michigan, Ann Arbor, MI, USA.
}

\section{Journal of Neuroendocrinology}

Correspondence to: Maria P. Cornejo, Calle $526 \mathrm{~s} / \mathrm{n}$ entre 10 y $11, \mathrm{PO}$ Box 403, La Plata, Buenos Aires 1900, Argentina (e-mail: mpaulacornejo @hotmail.com).
Given the current environment in most developed countries, it is a challenge to maintain a good balance between calories consumed and calories burned, although maintenance of metabolic balance is key to good health. Therefore, understanding how metabolic regulation is achieved and how the dysregulation of metabolism affects health is an area of intense research. Most studies focus on the hypothalamus, which is a brain area that acts as a key regulator of metabolism. Among the nuclei that comprise the hypothalamus, the arcuate nucleus is one of the major mediators in the regulation of food intake. The regulation of energy balance is also a key factor ensuring the maintenance of any species as a result of the dependence of reproduction on energy stores. Adequate levels of energy reserves are necessary for the proper functioning of the hypothalamicpituitary-gonadal axis. This review discusses valuable data presented in the 2015 edition of the International Workshop of Neuroendocrinology concerning the fundamental nature of the hormonal regulation of the hypothalamus and the impact on energy balance and reproduction.

Key words: energy balance, hypothalamus, reproduction

\section{Introduction}

Given the current environment in most developed countries, it is a challenge to maintain a good balance between calories consumed and calories burned, although maintenance of metabolic balance is key to good health. The worldwide increase in the incidence of being overweight and obese demonstrates the difficulty that people have maintaining a proper energy balance. In 2014, 39\% of adults age $\geq 18$ years were overweight (body mass index $>25 \mathrm{~kg} / \mathrm{m}^{2}$ ), whereas $11 \%$ of men and $15 \%$ of women were obese (body mass index $>32 \mathrm{~kg} / \mathrm{m}^{2}$ ) (1). This leads to an estimate of 1.9 billion overweight adults worldwide, of whom 600 million are obese. The risks associated with being overweight include cardiovascular disease and type 2 diabetes mellitus, amongst others. Therefore, understanding how metabolic regulation is achieved and how the dysregulation of metabolism affects health is of great importance.

The hypothalamus is a brain area that acts as a key regulator of metabolism and mediates numerous processes, including food intake, body temperature, sexual behaviour and reproduction, circadian rhythms and emotional responses. The hypothalamus, comprising many distinct neuronal nuclei, integrates neural, endocrine and metabolic signals. Among these nuclei, the importance of the arcuate nucleus (ARC) in the regulation of energy balance is well known (2). Its position is adjacent to the median eminence, allowing the ARC to sense circulating signals such as leptin, ghrelin and insulin, amongst others. Through changes in the activity of its neuronal populations and through many diverse and widespread outputs, the ARC is a major participant in the regulation of energy metabolism.

The regulation of energy balance is not only important for the survival of one individual, but also is a key factor ensuring the maintenance of any species as a result of the dependence of reproduction on energy stores (3). Adequate levels of energy reserves are necessary for the proper functioning of the hypothalamic-pituitarygonadal axis. The neuroendocrine players that link energy balance with the reproductive system include hormones and neuropeptides that act on hypothalamic gonadotrophin-releasing hormone neurones. As an example, leptin is one of the hormones recognised as 
a modulator of the reproductive axis, as well as a modulator of energy balance. Thus, the importance of energy metabolism and its regulation to guarantee reproduction is well established.

This review discusses valuable data presented in the 2015 edition of the International Workshop of Neuroendocrinology concerning the fundamental nature of the neuroendocrine regulation of hypothalamic neurones and the impact on energy balance and reproduction.

\section{Main hypothalamic systems regulating metabolism}

Pro-opiomelanocortin (POMC) and agouti-related peptide $(\mathrm{AgRP})$ neurones in energy balance regulation: beyond the peptides

The central nervous system (CNS) plays a major role in maintaining a balance between the energy required for survival and the energy provided by feeding. To fully understand the central regulation of energy balance, it is essential to understand the complete compliment of neurotransmitters involved. Clearly, the peptide transmitters released from hypothalamic AgRP and POMC neurones are important regulators of energy balance $(4,5)$. However, it has become increasingly clear that these neurones also utilise amino acid transmitters that may also impact energy balance regulation. Therefore, many recent studies have focused on the production, release and consequence of the amino acid transmitters GABA and glutamate from AgRP and POMC neurones.

Indications that AgRP and POMC neurones likely use a mix of peptide and amino acid transmitters date back several decades to immunoelectron microscopy studies showing both dense-core and smallclear vesicles in the axon terminals of these neurones $(4,6)$. A role for amino acid transmitters in food intake and metabolism was suggested as a result of pharmacologic studies carried out from the 1970 s up to the 1990s. However, experiments exploring the potential significance of GABA or glutamate release from neurones in energy balance circuits were not possible until advances were made in genetic manipulation. Using genetic approaches to delete the orexigenic peptides neuropeptide Y (NPY) or AgRP or both, it was found that energy balance could be largely maintained in the absence of these peptides $(7,8)$, whereas ablation of the AgRP/NPY neurones in adult mice blunted food intake and caused rapid wasting $(9,10)$. This unexpected difference between peptide deletion and neuronal ablation was eventually attributed to the loss of GABA co-release when the neurones were ablated as a whole (11), resulting in renewed interest in amino acid transmitters in energy balance circuits. Optogenetic and other approaches have been used to further show the importance of GABA release from AgRP neurones in the stimulation of food intake and the downstream targets of AgRP neurone-derived GABA release are beginning to be revealed $(11,12)$.

The release of GABA from AgRP neurones can be dynamically regulated. Fasting causes increased GABA release, whereas leptin decreases GABA release from AgRP neurones onto POMC neurones (13). Although inhibition of POMC neurones may not be a necessary contributor to increased food intake upon robust AgRP neurone stimulation (14), the high degree of connectedness from AgRP to POMC neurones makes this a convenient synapse for examining changes in GABA release from AgRP neurones. It is tempting to infer that altered release at one target site likely reflects similar changes in other target regions, although this may not be the case. Neurones can release different sets of chemical transmitters from distinct fibres $(15,16)$ and terminals may preferentially express one transmitter or another from a given cell type $(17,18)$. Therefore, it will be necessary to determine how changes in the activity of POMC or AgRP neurones affects GABA release in specific target sites to fully understand the dynamic regulation imposed by these neurones under select conditions.

Unlike AgRP neurones that appear to use only GABA as their amino acid transmitter, POMC neurones appear heterogeneous in their amino acid phenotype with approximately 50\% of POMC neurones being GABAergic and approximately 10-40\% being glutamatergic $(19,20)$. Interestingly, the amino acid transmitter phenotype of POMC neurones appears to be plastic throughout development, with a large proportion of POMC neurones showing glutamatergic markers during the early postnatal period and tapering off into adulthood (21). The genetic deletion of the vesicular glutamate transporter vGlut2 to prevent glutamate release specifically from POMC neurones causes a modest sex-specific increase in body weight in male mice maintained on a high-fat diet (21). However, this phenotype may reflect a developmental effect because vGlut2 was constitutively deleted from POMC neurones and potentially from a subset of other neurones that transcribe the POMC gene briefly during development (22). Therefore, additional studies are needed to determine the role of glutamate release from POMC neurones in adulthood and to begin to explore the functional consequence of GABA release from POMC neurones. Additionally, determining whether GABAergic and glutamatergic POMC neurones represent otherwise distinct subpopulations of POMC neurones and whether the developmental reduction in glutamatergic phenotype is important in energy balance regulation will add to a more complete understanding and inform future studies that may manipulate or examine POMC neurones in a subtype-specific manner.

By identifying and understanding the actions of the array of transmitters involved in energy balance regulation, it will be possible to better identify potential points of dysfunction and perhaps therapeutic targets. The recent advances described above add essential information regarding the complex actions of POMC and AgRP neurones. Although there is much more to learn regarding the roles of amino acid transmitters in energy balance, the recognition that POMC and AgRP neurones use both peptide and amino acid transmitters to effect a variety of responses on distinct timescales in a state-dependent manner reflects a significant increase in the understanding of this system.

\section{Hormones regulating hypothalamic systems controlling metabolism}

Ghrelin and the regulation of feeding: an important player for energy homeostasis

To achieve the regulation of energy balance, CNS circuits must be able to interact with the endocrine system, which provides 
peripheral signals that indicate body energy status. Among them, ghrelin is the only mammalian peptide hormone known to increase food intake. Ghrelin acts primarily on CNS centres to affect not only homeostatic-driven food intake, but also to regulate hedonicdriven feeding.

Ghrelin is a 28-amino acid octanoylated peptide secreted by cells located within the gastrointestinal tract. It was first discovered as the endogenous ligand of the growth hormone secretagogue receptor 1a (GHSR1a), with the ability to stimulate the secretion of growth hormone from the anterior pituitary gland (23). Further studies in the area of ghrelin led to the discovery of a role for this hormone in the regulation of several processes, including food intake, glucose metabolism, gastrointestinal tract motility and stress- and anxiety-related behaviours, amongst others (24). Plasma ghrelin levels rise before meals and decrease after the ingestion of food (25). This pattern of variation promoted the idea of ghrelin as a 'meal initiation' signal, which held up for many years, although this simplistic view is now beginning to be displaced (26).

Ghrelin acts on the CNS by binding to GHSR1a, which is a Gprotein coupled receptor highly expressed in brain centres associated with food intake (27). The main neuronal targets that mediate the orexigenic action of ghrelin are the ARC of the hypothalamus and the dorsal vagal complex (DVC) of the brainstem (28). The extent to which ghrelin is able to reach these sites of action is a matter of debate (29). These two brain areas display the important feature of having a circumventricular organ associated: the median eminence, which lies adjacent to the ARC, and the area postrema, which is part of the DVC. Circumventricular organs are specialised brain regions that lack the normal blood-brain barrier and present fenestrated capillaries that allow peripheral signals to reach their neuronal targets (30). In the case of the ARC, it is assumed that ghrelin is able to freely diffuse through the median eminence and reach GHSR1a-expressing neurones (31). Regarding the DVC, ghrelin could directly activate GHSR1a-expressing neurones of the area postrema, which in turn regulate their targets in the brainstem and hypothalamus (32).

The ARC contains two major neuronal populations with opposite effects on food intake: the orexigenic AgRP/NPY-expressing neurones and the anorexigenic POMC-expressing neurones. The importance of the ARC as a mediator of the orexigenic action of ghrelin emerges from the fact that the absence of AgRP/NPY neurones eliminates the ghrelin-triggered increase in food intake (33). Another piece of evidence supporting a key role of the ARC in mediating the orexigenic effects of ghrelin is that AgRP/NPY neurones express high levels of GHSR1a mRNA (34). The AgRP/NPY neurones send projections to other hypothalamic nuclei such as the paraventricular nucleus (PVN), the dorsomedial nucleus of the hypothalamus (DMH) and the lateral hypothalamic area (LHA), which are all involved in the control of feeding. These hypothalamic nuclei also express GHSR1a mRNA and show ghrelin binding when biotin- and fluorescent-labelled ghrelin binding assays are performed $(31,35,36)$. Thus, the direct and/or indirect participation of these brain areas could be important for the regulation of food intake by ghrelin.
The DVC is another important brain area that mediates the orexigenic action of ghrelin. This brain region is made up of three nuclei: the nucleus of the solitary tract, the area postrema and the dorsal motor nucleus of the vagus. The expression of GHSR1a mRNA has been described in all three components of the DVC (27), suggesting that ghrelin can directly act on them. Indeed, it has been shown that the administration of ghrelin directly on the DVC promotes food intake (37). Additionally, i.c.v. infusion of ghrelin activates c-Fos (a marker of neuronal activation) expression in the area postrema and the nucleus of the solitary tract (38). Nevertheless, one study showed that peripheral administration of ghrelin to mice that selectively express GHSR1a in the DVC does not result in an increase in food intake (39). This evidence suggests that the DVC is a target of ghrelin with respect to regulating food intake but it is not sufficient to mediate the orexigenic action of ghrelin.

Considering that ghrelin is the only peptide hormone known to increase food intake, its relevance in the regulation of energy homeostasis is highlighted. Although the brain targets for the orexigenic action of ghrelin are well established, the exact molecular mechanisms by which this hormone regulates feeding are not completely understood. Unravelling these mechanisms is of extreme importance with respect to considering them as potential therapeutic targets in the treatment of pathologies that affect food intake.

\section{Oxysterols and liver $\mathrm{X}$ receptors (LXRs)}

Being overweight and obese are primarily linked to poor eating habits. A busy lifestyle induces an increase in the availability and consumption of fast foods. This type of food contains large amounts of animal fats, which contain a mixture of triglycerides, cholesterol and phospholipids. Cholesterol is necessary to guarantee the integrity and fluidity of the cell plasma membrane. It is produced by all animal cells and is also incorporated with the diet. At present, the quantity of cholesterol consumed represents an excess relative to the needs of human body. This implicates that the organism must be able to metabolise it and one important way is via the oxidation of cholesterol to oxysterols.

The oxysterols are involved in different mechanisms related to the removal of cholesterol from cells (40). These compounds are capable of binding to specific proteins called LXRs acting as their endogenous ligands (41-43). The functional LXRs exist as two isoforms: LXR $\alpha$ and LXR $\beta$. The first is mainly expressed in the liver and, to a lesser extent in the gut, adipose tissue, kidney, spleen and macrophages, whereas LXR $\beta$ is expressed in almost all tissues (40). Upon exposure to excessive accumulation of intracellular cholesterol oxides, LXRs activate a programme of gene expression for limiting the pathogenic accumulation of cholesterol (44). In the intestine, activation of LXRs decreases cholesterol absorption from the diet by promoting the expression of excretion transporters such as ABCA1, ABCG5 and ABCG8 (45). In macrophages, LXRs cause a rapid increase in the expression of genes involved in the formation of high-density lipoprotein and reverse cholesterol transport (46). In the liver, LXR activation promotes the direct conversion of excessive cholesterol to bile acids through the regulation of the limiting enzyme $7 \alpha$ hydroxylase (CYP7a) (40). 
In addition to the regulation of cholesterol homeostasis in multiple tissues, LXRs are also intimately involved in the control of hepatic lipid metabolism and in the physiological regulation of carbohydrate metabolism (47). Studies demonstrated that LXR agonists improve glucose tolerance in a mouse model of diet-induced insulin resistance. Treatment with synthetic LXR ligands alters the expression of genes in the liver and adipose tissue and causes a decrease in hepatic glucose production and an increase in glucose uptake by adipocytes. Furthermore, activation of LXRs indirectly suppresses the expression of hepatic gluconeogenesis enzymes (phosphoenolpyruvatecarboxykinase and glucose 6-phosphatase), whereas, in adipose tissue, LXRs regulate the expression of the insulin-sensitive glucose transporter GLUT4 (48). Further studies suggest that LXR $\beta$ in particular plays an important role in pancreatic insulin secretion and LXR activators promote insulin secretion (47). LXR ligands have also proven to be effective in other studies of insulin resistance and type 2 diabetes mellitus, in which spontaneously diabetic or age-developed glucose intolerant rodent strains ( $d b / d b$ mice, ob/ob mice, fa/fa Zucker rats) were used to highlight the potential of LXR agonists as insulin sensitisers $(49,50)$.

Although the metabolic functions of the LXRs in peripheral organs have been widely investigated, little is known about the expression and functionality of LXRs in the brain. The activation of LXRs facilitates the excretion of cholesterol in the cerebellum and hippocampus (51). Recent studies show that the expression of LXR $\alpha$ and LXR $\beta$ in the hypothalamus is sensitive to triglycerides and serum insulin levels. Animals with glucose intolerance show an upregulation of $L X R \beta$ and a down-regulation of $L X R \alpha$ in the hypothalamus. In addition, a correlation between this LXR expression and triglyceride or insulin levels was described, indicating the importance of both subtypes in the risk of developing metabolic diseases (52). LXR $\beta$ expression in the hypothalamus correlates negatively with the area under the curve in glucose tolerance tests in control animals, whereas a positive correlation is found in rats with abnormal glucose tolerance $(52,53)$. The endogenous receptor agonists can also modulate LXR expression. The brain produces most of the 24(S)-hydroxycholesterol present in the body. This metabolite acts as an efficient LXR agonist (54) and is produced by cholesterol-24hydroxylase (CYP46A1). This enzyme converts cholesterol from degraded neurones into 24(S)-hydroxycholesterol to allow the removal of cholesterol from the brain and is induced by oxidative stress (55). Glucose has also been described to induce the expression of LXR target genes at physiological concentrations, although the data are controversial $(56,57)$.

The hypothalamus coordinates several complex homeostatic mechanisms and LXRs appear to be involved in some of them. The anatomical location of both receptor subtypes in the hypothalamus has been described using confocal microscopy (Fig. 1). LXR $\alpha$ was found in the periventricular nuclei, medial preoptic area (mPOA) and in the ventromedial nucleus of the hypothalamus $(\mathrm{VMH})$, whereas LXR $\beta$ was found in MPOA and the ARC (52). These nuclei contain neurones reactive to nutrient-related signals that induce neurochemical responses to regulate energy homeostasis (58). On the other hand, recent results show that in vitro treatment with glucose or insulin may alter LXR expression in hypothalamic cells.

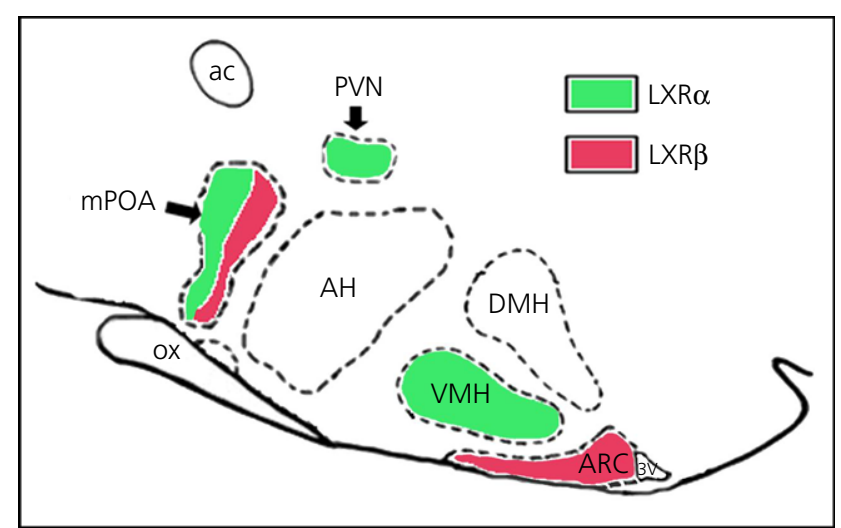

Fig. 1. Representative diagram of liver $X$ receptor (LXR) expression in the hypothalamic nuclei of rats: LXR localisation in the hypothalamic nuclei was evaluated by immunocytochemistry using specific antibodies. An LXR $\alpha$ signal was observed in the paraventricular (PVN) and ventromedial (VMH) nuclei, whereas an LXR $\beta$ signal was found in the arcuate (ARC) nucleus; both LXR immunosignals were detected in the median preoptic area (mPOA) expressed in different cell types (52). DMH, dorsomedial nucleus of hypothalamus; $\mathrm{AH}$, anterior hypothalamic area; ac, anterior commissure; ox, optic chiasm; $3 V_{\text {, }}$ third ventricle.

Glucose concentrations higher than $5.5 \mathrm{mM}$ decrease LXR $\beta$ expression, whereas insulin treatment produces a similar effect only in the presence of $8.5 \mathrm{mM}$ glucose. In both conditions, LXR $\alpha$ expression is unaffected (59). In vitro treatment with lipids also modifies the expression of this receptor. Incubation with cholic acid (4 h) and cholesterol increases the expression of $L X R \alpha$, and cholic acid also promotes the expression of ABCA1. These results suggest that hypothalamic LXR $\beta$ is mainly sensitive to carbohydrate changes (47), whereas $L X R \alpha$ responds to lipid changes (60).

The data presented above indicate that oxysterols and LXRs are important players in the regulation of cholesterol metabolism in several organs. In addition, they mediate cholesterol removal from neurones in the CNS. There is also evidence that LXR expression in the hypothalamus is sensitive to nutrient levels, which suggests that they are involved in the regulation of energy balance. Thus, future studies that aim to understand the role that oxysterols and LXRs play in the regulation of energy metabolism would be of great interest.

\section{Food intake and metabolism: intertwined regulation by dopamine and prolactin}

As mentioned at the beginning of this review, maintaining a proper energy balance is a key factor to guarantee reproduction. Metabolic adaptations to store energy during pregnancy in preparation for future demands is a biological allostatic hallmark in evolution. Females display a strong hyperphagia during pregnancy and lactation. The hormone prolactin may be a major factor mediating this hyperphagia $(61,62)$, probably sustained by leptin-resistant hypothalamic centres controlling food intake (63).

Prolactin acts on peripheral tissues by activating a cytokine receptor (prolactin receptor; PRLR) of which there are long and short isoforms (64). Prolactin can reach the brain through an active 
re-uptake mechanism similar to the transport mechanisms described for leptin and insulin (65). In the brain, PRLR has been localised in the striatum, as well as in a number of hypothalamic nuclei associated with food intake and metabolism, including the ARC, VMH, PVN and the DMH (61). The presence of PRLR in brain areas associated with the regulation of energy balance and food intake, as well as in white and brown adipose tissue, liver and pancreas, raises the possibility that prolactin is involved in the regulation of energy balance acting at different levels (66) (Fig. 2).

Consistent with the hypothesis that prolactin has a significant role in the regulation of body weight, prolactin administration stimulates food intake $(67,68)$, whereas PRLR-deficient mice exhibit lower body weight and a reduced fat mass (69). Nevertheles, female mice lacking dopamine D2 receptors (D2Rs), Drd2 ${ }^{-/}$mice, exhibit chronic hyperprolactinaemia and pituitary lactotroph hyperplasia $(70,71)$ but similar body weight compared to wild-type females and only a minimal increase in food intake (72). However, Drd2 ${ }^{-/}$mice may not be an optimal model for studying the effects of chronic hyperprolactinaemia on energy balance given the fundamental importance of central D2Rs in food intake, reward mechanisms related to feeding behaviour $(73,74)$ and growth hormone-releasing hormone-growth hormone regulation (75).

To unravel the role of elevated prolactin levels, with intact central D2Rs, lactotroph-specific D2R knockout (lacDrd2KO) female mice provide a unique model. In lacDrd2KO female mice, serum prolactin levels are chronically elevated and mice are subfertile, with altered oestrous cycles (76). Consistent with the presence of functional brain D2Rs, the haloperidol-induced catatonia test is normal and the growth hormone axis is preserved (77). In lacDrd2KO female mice, there is a marked increase in body weight, food intake and adiposity. In correlation with adiposity accretion, serum leptin is markedly elevated but hypothalamic anorexigenic peptides do not indicate leptin resistance. Hypothalamic POMC mRNA levels, as well

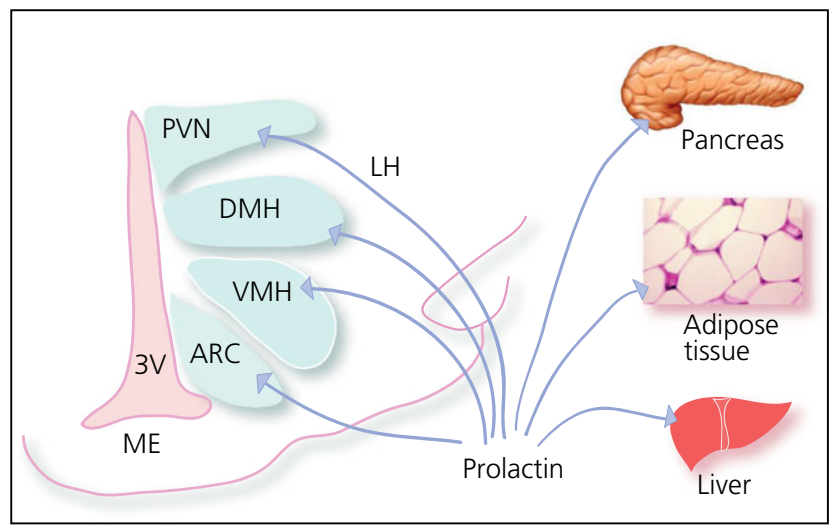

Fig. 2. Prolactin receptor (PRLR) in brain and tissues. In the rat brain, PRLR has been localised in a number of hypothalamic nuclei associated with food intake and metabolism, including the arcuate nucleus (ARC), ventromedial nucleus of the hypothalamus (VMH), paraventricular hypothalamic nucleus (PVN) and the dorsomedial nucleus of the hypothalamus (DMH). PRLR has also been described in the pancreas, adipose tissue and liver. ME, median eminence; $L H$, lateral hypothalamic area, $3 V_{\text {, third ventricle. }}$ as intermediate pituitary levels of $\boldsymbol{\alpha}$-melanocyte stimulating hormone $(\alpha-M S H)$, which are anorexigenic, are normal. Furthermore, mRNA levels of the orexigenic NPY, which are usually down-regulated by leptin, are increased.

Similarly, high prolactin levels in pregnancy or lactation induce a state of leptin resistance to meet the metabolic demands of the dams (78). Both suckling and prolactin increase NPY expression in the $\mathrm{DMH}$, suggesting that prolactin might stimulate food intake by potentiating the effects of NPY input on the PVN (61).

On the other hand, in the global Drd2 $2^{-1-}$ knockout mouse, a loss of central D2Rs mediates a decrease in prepro-orexin (Ppo) mRNA levels and an increase in $\alpha$-MSH levels and, to some extent, these two anorexigenic events may offset the effect of prolactin on food intake. Therefore, functional central D2R signalling in the lacDrd2KO mouse maintains POMC and Ppo mRNA levels and the central orexigenic effect of prolactin is fully demonstrated (Fig. 3).

These data indicate that central D2Rs, which are key elements in food intake homeostasis, interact with prolactin levels.

In lacDrd2KO female mice, heavier gonadal and retroperitoneal fat pads, larger adipocytes, and heavier livers were found. Increased adiposity correlated with higher serum triglycerides and non-esterified fatty acids, with no changes in cholesterol or adiponectin. In adipose tissue, prolactin has been shown to up-regulate the expression of its receptor, stimulate adipocyte differentiation and inhibit lipolysis $(79,80)$. Adipose PRLR was not increased in the selective mutant, although lipolysis was decreased (76) and this may explain the increased adipocyte size found. Interestingly, the expression of a lipogenic enzyme, lipoprotein lipase, was also decreased in correlation with increased serum triglycerides. Livers were heavier in lacDrd2KO mutants. Abundant fat droplets were observed, as were a higher triglyceride content and PRLR mRNA levels. High fat content in the liver could not be attributed to changes in the

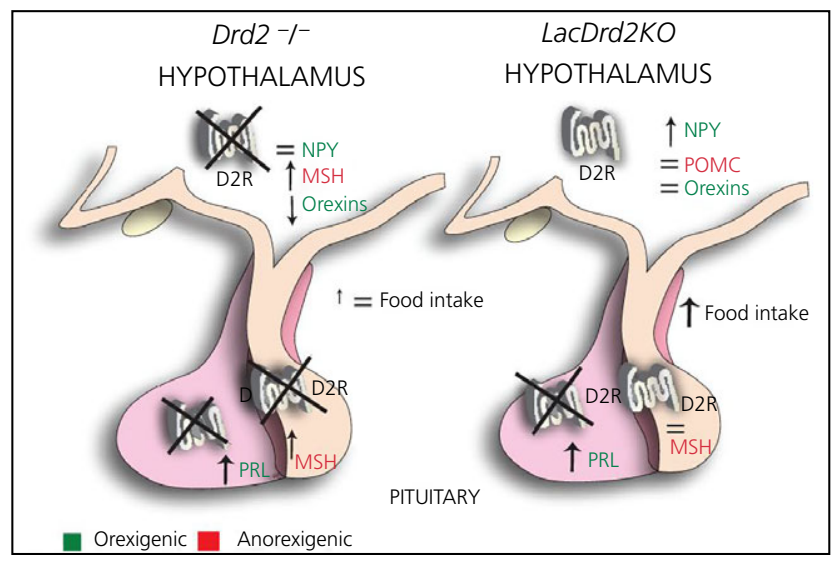

Fig. 3. Effect of global ( $\mathrm{Drd} 2^{-1-}$ ) and lactotroph specific D2R knockout (LacDrd2KO) mouse models on anorexigenic and orexigenic factors in the pituitary and hypothalamus. In $\mathrm{Drd}^{-1-}$ females, two anorexigenic events [an increase in $\boldsymbol{\alpha}$-melanocyte stimulating hormone (MSH) and a decrease of orexin precursors] may offset the orexigenic action of prolactin (PRL), whereas, in lacDrd2KO mice, both Pomc and Ppo are not modified, and prolactin activates Npy expression, resulting in increased food intake. NPY, neuropeptide Y; POMC, pro-opiomelanocortin. 
expression of lipogenic or lipolytic enzymes but, instead, to alteration of glucose homeostasis. In this respect, hyperprolactinaemic lacDrd2KO mice had glucose intolerance, and a blunted insulin response to glucose (76).

In conclusion, selective ablation of D2Rs from lactotrophs evokes persistent hyperprolactinaemia, which induces a state of leptin resistance and increases hypothalamic NPY levels, in correlation with a hyperphagic state. Increased food intake, together with prolactin acting at different organs, modifies energy metabolism. There is an increase in adiposity, higher serum non-esterified fatty acids and triglycerides. At the pancreatic level, the insulin response to glucose is impaired, which results in glucose intolerance, high serum glucose and hyperinsulinaemia. Altered glucose metabolism may be responsible for the increased lipid content in the liver. These results highlight the role of prolactin as a metabolic hormone acting on different organs to reinforce its role during pregnancy, which is to store energy for future demands.

\section{Impact of altered metabolism on reproductive function}

\section{Metabolic control of reproduction: focus on leptin signalling}

The processes involved in successful reproduction, including sexual maturation, production of gametes, pregnancy and lactation, are energetically demanding (81-83). As a consequence, conditions of low energy availability or high energy utilisation result in decreased activity of the reproductive axis. For example, gonadotrophin secretion and ovulation are compromised in females in negative energy balance as a result of inadequate feeding or excessive energy expenditure $(84,85)$. The interaction between these complex systems (metabolism and reproduction) is orchestrated by hypothalamic neurones that sense changes in circulating levels of metabolic cues and adapt the system to the individual nutritional condition. Among these cues, leptin is essential for the regulation of the reproductive axis.

Humans and mice with loss-of-function mutations in leptin (LEP/ Lep) or leptin receptor (LEPR/Lepr) genes are obese and infertile (86-88). Both have low circulating gonadotrophin levels, incomplete development of the reproductive tract and no pubertal maturation. Leptin is an adipocyte hormone secreted into the circulation in proportion to fat mass. It binds to cognate receptors expressed in many organs and tissues. The LepR is a class 1 cytokine receptor found in six isoforms (88-90). The LepR long form (LepRb) is the signalling isoform and contains a Box 3 motif associated with downstream phosphorylation of tyrosine residues. The best associated pathway described is the Janus kinase/signal transducer and activator of transcription (JAK/STAT) signalling pathway (91-94). Deletion of leptin-induced STAT3 signalling (Tyr1138, LRbS1138s/s mice) recapitulates the hyperphagic obesity and the well-described changes in the melanocortin system of the LepR deficient $(d b / d b)$ mice (95). However, disruption of STAT3 signalling in this mutant line has little effect on glycaemic control and fertility (95). The $s / s$ female mice show sexual maturation, development of the reproductive tract and ovarian signs of ovulation, suggesting that the effect of leptin on reproductive function is independent of the STAT3 signalling pathway (95).

Disruption of LepRb tyrosine residue 1107 (Tyr1107) blocks leptin-induced phosphorylation of STAT5. These mice develop mild obesity and show very small changes in oestrous cycle duration (96). However, conditional deletion of STAT5 in LepR cells causes no metabolic or reproductive deficits (97). Deletion of both STAT3 and STAT5 signalling produces mice with a phenotype similar to those with deletion of STAT3 alone (i.e. increased body weight and adiposity). On the other hand, mutation in Tyr985 residue of LepRb causes a lean phenotype potentially because of increased leptin sensitivity as a result of blockade of SOCS3 and phosphatases associated with feedback inhibition of leptin signalling (98). No reproductive phenotype was observed in Tyr985 mutant mice.

Leptin also recruits the phosphoinositide 3-kinase (PI3K) signalling pathways $(92,99-101)$. In hypothalamic slices, the acute effects of leptin on cell activity and feeding require intact PI3K $(99,100,102-105)$. However, the molecular mechanisms associated with these responses are not clear, although studies have suggested that phosphorylation of insulin receptor substrate-2 (IRS-2) is upstream of leptin-induced PI3K $(106,107)$. IRS-2 is expressed in hypothalamic neurones and IRS-2 knockout mice show metabolic dysfunction and infertility (108). Females have low sex hormones and deficient reproductive tract development. However, mice with conditional deletion of IRS-2 in LepR cells are fertile, although whether pubertal development, cyclicity and hormone levels are normal has not been reported (109).

$\mathrm{PI3K}$ is found as multiple classes of enzymes. Leptin recruits the class 1a PI3K comprising heterodimers of one regulatory and one catalytic subunit. The regulatory subunits are collectively called p85s and the catalytic subunits are called p110s $(110,111)$. The $p 110 \alpha$ and $p 110 \beta$ catalytic subunits are widely expressed, and global deletion of either one is incompatible with life (112115). However, 50\% loss-of-function of p110 $\alpha$ activity decreases insulin and leptin responsiveness, causing hyperphagia, glucose intolerance and increased fat mass (116). Both catalytic subunits are expressed in LepR neurones of the hypothalamus $(104,117)$. However, whether the lack of leptin-induced PI3K signalling results in metabolic or reproductive deficits has not been reported.

In summary, the role of leptin in reproductive control is well established. However, the molecular pathways associated with leptin action as a permissive factor for pubertal maturation and as a signal of energy sufficiency for successful reproduction are still unsettled.

\section{Sexual dimorphism in the control of metabolism}

\section{Sex steroids regulate metabolism}

The differences in metabolic function between males and females highlight the role of sex steroids in the regulation of energy balance and body composition. In this regard, androgens and oestrogens are primary regulators of metabolism in both sexes. The 
action of sex steroids is focused on the hypothalamic nuclei that regulate food intake and energy balance, although they also regulate metabolism in peripheral tissue (muscle, liver and adipose tissue) (Fig. 4). Oestrogens exert their effects through binding to the nuclear oestrogen receptors (ER) isoforms $\alpha(E R \alpha)$ and $\beta(E R \beta)$, or the membrane $G$ protein-coupled oestrogen receptor (GPER30), dictating the activation of genomic or nongenomic pathways, respectively. At the same time, androgens bind to androgen receptors (AR) located in the nucleus or the cytoplasm of cells, with both exerting their actions in the nucleus.

\section{Androgens modulate metabolism in females and males}

Multiple animal models and clinical studies have demonstrated that androgens play important roles in the control of metabolic function in both sexes. In males, androgens stimulate lean mass growth and inhibit fat accumulation (114). Therefore, it is not surprising that testosterone deficiency induces obesity, accumulation of visceral adipose tissue (VAT) and increases the risk of developing insulin resistance and diabetes mellitus (115). In females, androgen excess provokes a similar condition to androgen deficiency in males, including abdominal obesity, a pro-inflammatory profile and insulin resistance (116). The mechanisms associated with androgen deficiency-induced insulin-resistance probably include modifications in the muscle transcriptome, mainly a reduction in the expression of the transcription factor peroxisome proliferator-activated receptor- $\gamma$ coactivator $\alpha(\mathrm{PGC} 1 \alpha)$, which plays important roles in the stimulation of mitochondrial biogenesis and skeletal muscle oxidative fibres

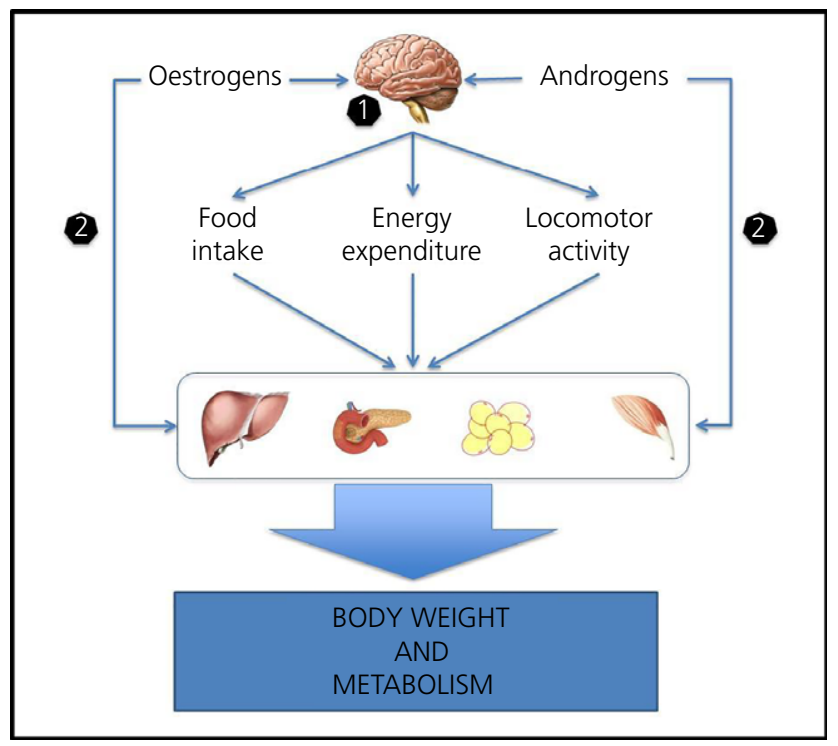

Fig. 4. Oestrogens and androgens regulate metabolic function. (1) Androgens and oestrogens act on the hypothalamus, mainly in the arcuate nucleus (ARC) and ventromedial nucleus of the hypothalamus (VMH), regulating food intake, energy expenditure and locomotor activity. This action impacts on the metabolic function of liver, pancreas, adipose tissue and muscle, leading to the regulation of body weight and whole-body metabolic function. (2) Moreover, androgens and oestrogens can directly modulate the function of these tissues.
(117). Moreover, testosterone and dihydrotestosterone (DHT) can modulate adipogenesis in subcutaneous adipose tissue (SAT) and VAT in both sexes. However, androgens can limit the number of mature adipose cells in females. By contrast, testosterone in males induces the proliferation of visceral pre-adipocytes (118).

It is difficult to isolate the role of androgens from the role of oestrogens with respect to metabolic function because androstenedione and testosterone are converted to oestrone and oestradiol, respectively, by the $\mathrm{P} 450$ aromatase. DHT, which cannot be metabolised to oestrogen, can be reduced by the aldo-ketoreductase family $1 \mathrm{C}$ to androstenediol, which has oestrogen-like activity via ER $\beta$ (119). However, AR knockout (ARKO) male mice develop late-onset obesity with an increase in both SAT and VAT. ARKO female mice lack these changes but present a reduction in energy expenditure (120), which demonstrates that androgens are directly involved in the control of body weight and metabolism.

Interestingly, ARs are more abundantly expressed in the brains of males than females, mainly in the $\mathrm{VMH}, \mathrm{ARC}$, anteroventral periventricular nucleus, mPOA and bed nucleus of the stria terminalis. In this regard, it has been observed that hypothalamic ARs are associated with the activation of STAT3 leptin-induced signalling in ARC neurones (121). In addition, in vitro studies demonstrate that ARs are necessary to maintain hypothalamic insulin sensitivity, which is mediated by the inhibition of nuclear factor-kappa B (122). In female mice, androgen-induced increase of visceral fat mass appears to be mediated by a decrease in hypothalamic POMC expression and POMC neuronal innervation to the $\mathrm{DMH}$, resulting in the failure of leptin to activate brown adipose tissue thermogenesis and energy expenditure (123). These antecedents indicate that the hypothalamic ARs contribute to the suppression of food intake and the control of whole-body metabolism in both males and females.

\section{Oestrogens modulate metabolism in females and males}

The metabolic role of oestrogens is better understood in female physiology. It is clear that the decline of ovarian function induces important changes in body composition, increasing the accumulation of total body fat, abdominal obesity and reducing energy expenditure (124). Interestingly, similar findings have been observed in female rats exposed to an inhibitor of the P450 aromatase. These animals present elevated androgens but reduced oestrogen levels and an increase in adiposity, larger adipose cells and insulin resistance (125).

Animal models show that oestrogens improve insulin sensitivity, body composition and the lipid profile in both sexes (126). Receptor-specific $\mathrm{KO}$ models have demonstrated that both receptors are involved in metabolic function. However, they can have different and sometimes antagonistic actions, with $\mathrm{ER} \alpha$ probably being more relevant than ER $\beta$ signalling (127). The deletion of $E R \alpha$ induces insulin resistance, dyslipidaemia, $\beta$-pancreatic cell dysfunction and impaired glucose tolerance. In the same way, the selective activation of ER $\alpha$ or ER $\beta$ by specific pharmacological agonists, propyIpyrazoletriol and diarylpropionitrile, respectively, has demonstrated similar effects (128). It appears that ER $\beta$ could have anti- 
obesogenic actions during high-fat diet challenge in mice, which is associated with the inhibition of PPAR $\gamma$-induced adipogenesis, as demonstrated in ER $\beta$ KO mice $(129,130)$. In this regard, it has been observed that the total and plasma membrane fraction of GLUT4 is strongly reduced in skeletal muscle of $E R \alpha \mathrm{KO}$ mice but not affected in ER $\beta$ KO mice (131).

In the hypothalamus, ER $\alpha$ expression is markedly higher than ER $\beta$ in the VMH, ARC, PVN, POA and LHA. Of interest, the hypothalamic expression of oestrogen and androgen receptors is dependent on sex and age, indicating the importance of metabolism on reproductive function (132). Brain deletion of $E R \alpha$ induces hyperphagia and decreased energy expenditure and locomotor activity, leading to fat accumulation in visceral depots (133). Although these functions are determined by different hypothalamic areas, the direct injection of oestradiol into the PVN, ARC and VMH is the most effective method of reducing food intake and body weight and increasing locomotor activity, especially in females (134). In this regard, the specific loss of $E R \alpha$ in ARC POMC neurones increases food intake but does not directly affect energy expenditure (133), whereas the deletion of ER $\alpha$ in VMH neurones decreases energy expenditure but does not affect food intake $(133,135)$. In addition to the metabolic effects exerted by their nuclear receptors, it has been observed that the deletion of oestrogen membrane receptor GPER30 increases body weight (136). In turn, the activation of the GPER30 alone is able to trigger the STAT3 signalling pathway. Interestingly, ER $\alpha$ KO mice exhibit altered leptin-induced STAT3 activation (137). Overall, these antecedents suggest a cross-talk between nuclear and/or membrane oestrogen receptors and leptin-induced STAT3 signalling in the control of food intake and energy expenditure.

In summary, it is clear that sex steroids are central regulators of metabolic function. Probably, androgens and oestrogens act coordinately at different organs such as brain, skeletal muscle, adipose tissue and liver. The different profile in sex steroids between females and males results in sex-dependent patterns of body composition, insulin sensitivity and energy expenditure.

\section{Concluding remarks}

The importance of the regulation of energy metabolism is highlighted by the fact that survival and reproduction strongly depend on energy levels. It is clear that the CNS regulation of energy homeostasis is principally mediated by the hypothalamus, which contains neuronal populations with the ability to sense nutrientrelated signals and affect food intake. This review highlights recent studies indicating that hypothalamic AgRP and POMC neurones utilise not only peptide transmitters to exert their roles, but also amino acid transmitters (GABA and glutamate) and this utilisation can be dynamically regulated depending on body energy status. The regulatory role of the hypothalamus is influenced by the action of peripheral hormones and metabolites produced by different organs, such as adipose tissue, gonads and gastrointestinal tract. In this review, the role of ghrelin, prolactin and oxysterols as participants in the regulation of metabolism has been discussed. Although these three molecules affect energy homeostasis and have their neuronal targets mainly located in the hypothalamus, their role becomes relevant in different states. Ghrelin is important when negative energy balance is present, stimulating food intake and preparing the body for the ingestion of food. Prolactin has a prominent role when females face pregnancy and lactation, promoting food intake with the final objective of storing energy for the future demands of the offspring. Oxysterols and their receptors are involved in the excretion of cholesterol when excessive cholesterol is present in cells, although recent studies have suggested that they are also implicated in the hypothalamic regulation of carbohydrates and lipid metabolism.

The hypothalamus is also important in the regulation of reproductive function, which is also influenced by body energy status. Leptin acts as a link between energy status (i.e. it is secreted in proportion to fat mass) with the reproductive axis acting on hypothalamic gonadotrophin neurones. This review has highlighted recent work that aimed to establish the molecular mechanism by which leptin modulates sexual maturation and fertility. It is also known that sex steroids are determinants of reproductive function and the present review has introduced valuable data showing the intertwined regulation of energy metabolism by oestrogens and androgens.

Altogether, the whole concert of hormones and metabolites that regulate energy metabolism act on interrelated pathways forming a complex network. The proper functioning of this network finally determines the capacity of an organism to survive and to breed. This review has discussed some of the advances made in areas that are part of this complex network, in the framework of an environment that predisposes humans to energy balance disorders. The efforts made in these research areas contribute to the overall objective of understanding the elaborate regulation of energy metabolism.

\section{Acknowledgements}

This work was supported by grants to the authors: MPC was supported by CONICET; MM was supported by FONDECYT 11130250; HC was supported by PIP-860 from CONICET, 06CM09 from the Catholic University of Cuyo and PICT0-0158 from the Catholic University of Cuyo and the Rene Baron Foundation; STH was supported by the NIH grant R01-DK078749 and an award from the Monfort Family Foundation; DBV was supported by CONICET, the Argentinean National Agency of Research Promotion and the Rene Baron Foundation; CFE was supported by the NIH grant R01-HD69702. MPC would like to thank Dr Mario Perello for all the comments that were extremely helpful for the composition of this manuscript. The authors declare that they have no conflicts of interest.

Received 14 December 2015, revised 31 March 2016, accepted 21 April 2016

\section{References}

1 World Health Organization. World Health Statistics. Geneva: World Health Organization, 2015.

2 Williams KW, Elmquist JK. From neuroanatomy to behavior: central integration of peripheral signals regulating feeding behavior. Nat Neurosci 2012; 15: 1350-1355. 
3 Hill JW, Elmquist JK, Elias CF. Hypothalamic pathways linking energy balance and reproduction. Am J Physiol Endocrinol Metab 2008; 294: E827-E832.

4 Mercer AJ, Hentges ST, Meshul CK, Low MJ. Unraveling the central proopiomelanocortin neural circuits. Neuroendocr Sci 2013; 7: 19.

5 Sobrino Crespo C, Perianes Cachero A, Puebla Jiménez L, Barrios V, Arilla Ferreiro E. Peptides and food intake. Diabetes 2014; 5: 58.

6 Cowley MA, Smart JL, Rubinstein M, Cerdán MG, Diano S, Horvath $T L$, Cone RD, Low MJ. Leptin activates anorexigenic POMC neurons through a neural network in the arcuate nucleus. Nature 2001; 411: 480-484.

7 Erickson JC, Clegg KE, Palmiter RD. Sensitivity to leptin and susceptibility to seizures of mice lacking neuropeptide Y. Nature 1996; 381: 415-418.

8 Qian S, Chen $H$, Weingarth D, Trumbauer ME, Novi DE, Guan X, Yu H, Shen Z, Feng Y, Frazier E, Chen A, Camacho RE, Shearman LP, Gopal-Truter S, MacNeil DJ, Van der Ploeg LH, Marsh DJ. Neither agouti-related protein nor neuropeptide $Y$ is critically required for the regulation of energy homeostasis in mice. Mol Cell Biol 2002; 22: 5027-5035.

9 Bewick GA, Gardiner JV, Dhillo WS, Kent AS, White NE, Webster Z, Ghatei MA, Bloom SR. Postembryonic ablation of AgRP neurons in mice leads to a lean, hypophagic phenotype. FASEB J 2005; 19: 16801682.

10 Gropp E, Shanabrough M, Borok E, Xu AW, Janoschek R, Buch T, Plum L, Balthasar N, Hampel B, Waisman A, Barsh GS, Horvath TL, Brüning JC. Agouti-related peptide-expressing neurons are mandatory for feeding. Nat Neurosci 2005; 8: 1289-1291.

11 Wu Q, Palmiter RD. GABAergic signaling by AgRP neurons prevents anorexia via a melanocortin-independent mechanism. Eur J Pharmacol 2011; 660: 21-27.

12 Krashes MJ, Shah BP, Koda S, Lowell BB. Rapid versus delayed stimulation of feeding by the endogenously released AgRP neuron mediators GABA, NPY, and AgRP. Cell Metab 2013; 18: 588-595.

13 Dicken MS, Hughes AR, Hentges ST. Gad1 mRNA as a reliable indicator of altered GABA release from orexigenic neurons in the hypothalamus. Eur J Neurosci 2015; 42: 2644-2653.

14 Atasoy D, Betley JN, Su HH, Sternson SM. Deconstruction of a neural circuit for hunger. Nature 2012; 488: 172-177.

15 Fisher JM, Sossin W, Newcomb R, Scheller RH. Multiple neuropeptides derived from a common precursor are differentially packaged and transported. Cell 1988; 54: 813-822.

16 Sossin WS, Sweet-Cordero A, Scheller RH. Dale's hypothesis revisited: different neuropeptides derived from a common prohormone are targeted to different processes. Proc Natl Acad Sci USA 1990; 87: 4845-4848.

17 Koch $M$, Varela L, Kim JG, Kim JD, Hernández-Nuño F, Simonds SE, Castorena CM, Vianna CR, Elmquist JK, Morozov YM, Rakic $P$, Bechmann I, Cowley MA, Szigeti-Buck K, Dietrich MO, Gao X, Diano S, Horvath TL. Hypothalamic POMC neurons promote cannabinoidinduced feeding. Nature 2015; 519: 45-50.

18 Schöne C, Burdakov D. Glutamate and GABA as rapid effectors of hypothalamic 'peptidergic' neurons. Front Behav Neurosci 2012; 6: 81.

19 Jarvie BC, Hentges ST. Expression of GABAergic and glutamatergic phenotypic markers in hypothalamic proopiomelanocortin neurons. $J$ Comp Neurol 2012; 520: 3863-3876.

20 Wittmann G, Hrabovszky E, Lechan RM. Distinct glutamatergic and GABAergic subsets of hypothalamic pro-opiomelanocortin neurons revealed by in situ hybridization in male rats and mice. J Comp Neurol 2013; 521: 3287-3302.

21 Dennison CS, King CM, Dicken MS, Hentges ST. Age-dependent changes in amino acid phenotype and the role of glutamate release from hypothalamic proopiomelanocortin neurons. J Comp Neurol 2016; 524: 1222-1235.

22 Padilla SL, Carmody JS, Zeltser LM. Pomc-expressing progenitors give rise to antagonistic neuronal populations in hypothalamic feeding circuits. Nat Med 2010; 16: 403-405.
23 Kojima $M$, Hosoda $H$, Date $Y$, Nakazato $M$, Matsuo $H$, Kangawa $K$. Ghrelin is a growth-hormone-releasing acylated peptide from stomach. Nature 1999; 402: 656-660.

24 Kojima M, Kangawa K. Ghrelin: structure and Function. Physiol Rev 2005; 85: 495-522.

25 Cummings DE. Ghrelin and the short- and long-term regulation of appetite and body weight. Physiol Behav 2006; 89: 71-84.

26 Müller TD, Nogueiras $R$, Andermann ML, Andrews ZB, Anker SD, Argente J, Batterham RL, Benoit SC, Bowers CY, Broglio F, Casanueva FF, D'Alessio D, Depoortere I, Geliebter A, Ghigo E, Cole PA, Cowley M, Cummings DE, Dagher $A$, Diano $S$, Dickson SL, Diéguez $C$, Granata $R$, Grill HJ, Grove K, Habegger KM, Heppner K, Heiman ML, Holsen L, Holst $B$, Inui $A$, Jansson JO, Kirchner $H$, Korbonits $M$, Laferrère $B$, LeRoux CW, Lopez M, Morin S, Nakazato M, Nass R, Perez-Tilve D, Pfluger PT, Schwartz TW, Seeley RJ, Sleeman M, Sun Y, Sussel L, Tong J, Thorner MO, van der Lely AJ, van der Ploeg LH, Zigman JM, Kojima M, Kangawa K, Smith RG, Horvath T, Tschöp MH. Ghrelin. Mol Metab 2015; 4: 437460.

27 Zigman JM, Jones JE, Lee CE, Saper CB, Elmquist JK. Expression of ghrelin receptor mRNA in the rat and the mouse brain. $J$ Comp Neurol 2006; 494: 528-548.

28 Mason BL, Wang Q, Zigman JM. The central nervous system sites mediating the orexigenic actions of ghrelin. Annu Rev Physiol 2014; 76: 519-533.

29 Cabral A, De Francesco PN, Perello M. Brain circuits mediating the orexigenic action of peripheral ghrelin: narrow gates for a vast kingdom. Neuroendocr Sci 2015; 6: 44.

30 Hoyda TD, Smith PM, Ferguson AV. Gastrointestinal hormone actions in the central regulation of energy metabolism: potential sensory roles for the circumventricular organs. Int J Obes 2009; 33: S16-S21.

31 Schaeffer $M$, Langlet $F$, Lafont $C_{\text {, Molino }}$, Hodson DJ, Roux T, Lamarque $L$, Verdié $P$, Bourrier $E$, Dehouck $B$, Banères JL, Martinez J, Méry PF, Marie J, Trinquet E, Fehrentz JA, Prévot V, Mollard P. Rapid sensing of circulating ghrelin by hypothalamic appetite-modifying neurons. Proc Natl Acad Sci USA 2013; 110: 1512-1517.

32 Fry $M$, Ferguson AV. The sensory circumventricular organs: brain targets for circulating signals controlling ingestive behavior. Physiol Behav 2007; 91: 413-423.

33 Chen HY, Trumbauer ME, Chen AS, Weingarth DT, Adams JR, Frazier EG, Shen Z, Marsh DJ, Feighner SD, Guan XM, Ye Z, Nargund RP, Smith RG, Van der Ploeg LH, Howard AD, MacNeil DJ, Qian S. Orexigenic action of peripheral ghrelin is mediated by neuropeptide $Y$ and agouti-related protein. Endocrinology 2004; 145: 2607-2612.

34 Willesen MG, Kristensen P, Rømer J. Co-localization of growth hormone secretagogue receptor and NPY mRNA in the arcuate nucleus of the rat. Neuroendocrinology 1999; 70: 306-316.

35 Cowley MA, Smith RG, Diano S, Tschöp M, Pronchuk N, Grove KL, Strasburger CJ, Bidlingmaier $M$, Esterman $M$, Heiman ML, GarciaSegura LM, Nillni EA, Mendez $P$, Low MJ, Sotonyi $P$, Friedman JM, Liu H, Pinto S, Colmers WF, Cone RD, Horvath TL. The distribution and mechanism of action of ghrelin in the CNS demonstrates a novel hypothalamic circuit regulating energy homeostasis. Neuron 2003; 37: 649-661.

36 Cabral A, Fernandez G, Perello M. Analysis of brain nuclei accessible to ghrelin present in the cerebrospinal fluid. Neuroscience 2013; 253: 406-415.

37 Faulconbridge LF, Cummings DE, Kaplan JM, Grill HJ. Hyperphagic effects of brainstem ghrelin administration. Diabetes 2003; 52: 22602265.

38 Lawrence $\mathrm{CB}$, Snape $\mathrm{AC}$, Baudoin FM-H, Luckman SM. Acute central ghrelin and $\mathrm{GH}$ secretagogues induce feeding and activate brain appetite centers. Endocrinology 2002; 143: 155-162. 
39 Scott MM, Perello M, Chuang J-C, Sakata I, Gautron L, Lee CE, Lauzon $D$, Elmquist JK, Zigman JM. Hindbrain ghrelin receptor signaling is sufficient to maintain fasting glucose. PLoS One 2012; 7: e44089.

40 Björkhem I. Five decades with oxysterols. Biochimie 2013; 95: 448454.

41 Lehmann JM, Kliewer SA, Moore LB, Smith-Oliver TA, Oliver BB, Su J-L, Sundseth SS, Winegar DA, Blanchard DE, Spencer TA, Willson TM. Activation of the nuclear receptor LXR by oxysterols defines a new hormone response pathway. J Biol Chem 1997; 272: 3137-3140.

42 Janowski BA, Grogan MJ, Jones SA, Wisely GB, Kliewer SA, Corey EJ, Mangelsdorf DJ. Structural requirements of ligands for the oxysterol liver X receptors LXR $\alpha$ and LXRB. Proc Natl Acad Sci USA 1999; 96: 266-271.

43 Jakobsson T, Treuter E, Gustafsson J- $\AA$, Steffensen KR. Liver X receptor biology and pharmacology: new pathways, challenges and opportunities. Trends Pharmacol Sci 2012; 33: 394-404.

44 Tontonoz $\mathrm{P}$, Mangelsdorf DJ. Liver $\mathrm{X}$ receptor signaling pathways in cardiovascular disease. Mol Endocrinol 2003; 17: 985-993.

45 Bonamassa B, Moschetta A. Atherosclerosis: lessons from LXR and the intestine. Trends Endocrinol Metab 2013; 24: 120-128.

46 Tangirala RK, Bischoff ED, Joseph SB, Wagner BL, Walczak R, Laffitte $B A$, Daige $C L$, Thomas $D$, Heyman RA, Mangelsdorf DJ, Wang $X$, Lusis AJ, Tontonoz $P$, Schulman IG. Identification of macrophage liver $X$ receptors as inhibitors of atherosclerosis. Proc Natl Acad Sci USA 2002; 99: 11896-11901.

47 Gerin I, Dolinsky VW, Shackman JG, Kennedy RT, Chiang S-H, Burant CF, Steffensen KR, Gustafsson J, MacDougald OA. LXR $\beta$ is required for adipocyte growth, glucose homeostasis, and $\beta$ cell function. J Biol Chem 2005; 280: 23024-23031.

48 Cao G, Liang Y, Broderick CL, Oldham BA, Beyer TP, Schmidt RJ, Zhang $Y$, Stayrook KR, Suen C, Otto KA, Miller AR, Dai J, Foxworthy P, Gao $H_{\text {, }}$ Ryan TP, Jiang XC, Burris TP, Eacho PI, Etgen GJ. Antidiabetic action of a liver $X$ receptor agonist mediated by inhibition of hepatic gluconeogenesis. J Biol Chem 2003; 278: 1131-1136.

49 Chisholm JW, Hong J, Mills SA, Lawn RM. The LXR ligand T0901317 induces severe lipogenesis in the $\mathrm{db} / \mathrm{db}$ diabetic mouse. J Lipid Res 2003; 44: 2039-2048.

50 Grefhorst A, van Dijk TH, Hammer A, van der Sluijs FH, Havinga R, Havekes LM, Romijn JA, Groot PH, Reijngoud DJ, Kuipers F. Differential effects of pharmacological liver $X$ receptor activation on hepatic and peripheral insulin sensitivity in lean and ob/ob mice. Am J Physiol Endocrinol Metab 2005; 289: E829-E838.

51 Whitney KD, Watson MA, Collins JL, Benson WG, Stone TM, Numerick MJ, Tippin TK, Wilson JG, Winegar DA, Kliewer SA. Regulation of cholesterol homeostasis by the liver $\mathrm{X}$ receptors in the central nervous system. Mol Endocrinol 2002; 16: 1378-1385.

52 Kruse MS, Rey M, Vega MC, Coirini H. Alterations of LXR $\alpha$ and LXR $\beta$ expression in the hypothalamus of glucose-intolerant rats. J Endocrinol 2012; 215: 51-58.

53 Kruse MS, Vega MC, Rey M, Coirini H. Sex differences in LXR expression in normal offspring and in rats born to diabetic dams. J Endocrinol 2014; 222: 53-60.

54 Björkhem I, Lütjohann D, Diczfalusy U, Ståhle L, Ahlborg G, Wahren J. Cholesterol homeostasis in human brain: turnover of 24S-hydroxycholesterol and evidence for a cerebral origin of most of this oxysterol in the circulation. J Lipid Res 1998; 39: 1594-1600.

55 Ohyama $Y$, Meaney $S$, Heverin $M$, Ekström L, Brafman A, Shafir $M$, Andersson $U$, Olin $M$, Eggertsen $G$, Diczfalusy $U$, Feinstein $E$, Björkhem I. Studies on the transcriptional regulation of cholesterol 24-hydroxylase (CYP46A1) marked insensitivity toward different regulatory axes. J Biol Chem 2006; 281: 3810-3820.
56 Mitro N, Mak PA, Vargas L, Godio C, Hampton E, Molteni V, Kreusch A, Saez E. The nuclear receptor LXR is a glucose sensor. Nature 2007; 445: 219-223.

57 Denechaud P-D, Bossard P, Lobaccaro J-MA, Millatt L, Staels B, Girard J, Postic C. ChREBP, but not LXRs, is required for the induction of glucose-regulated genes in mouse liver. J Clin Invest2008; 118: 956-964.

58 Bantubungi K, Prawitt J, Staels B. Control of metabolism by nutrientregulated nuclear receptors acting in the brain. J Steroid Biochem Mol Biol 2012; 130: 126-137.

59 Kruse MS, Rey M, Coirini H. Abstracts of the II Annual Meeting - Sociedad de Biología de Cuyo - II Annual Meeting of the Cuyo Biology Society, 2015: 39.

60 Peet DJ, Turley SD, Ma W, Janowski BA, Lobaccaro J-MA, Hammer RE, Mangelsdorf DJ. Cholesterol and bile acid metabolism are impaired in mice lacking the nuclear oxysterol receptor LXRo. Cell 1998; 93: 693704.

61 Woodside B. Prolactin and the hyperphagia of lactation. Physiol Behav 2007; 91: 375-382

62 García MC, López M, Gualillo O, Seoane LM, Diéguez C, Señarís RM. Hypothalamic levels of NPY, MCH, and prepro-orexin mRNA during pregnancy and lactation in the rat: role of prolactin. FASEB $J$ 2003; 17: 1392-1400.

63 Naef L, Woodside B. Prolactin/leptin interactions in the control of food intake in rats. Endocrinology 2007; 148: 5977-5983.

64 Freeman ME, Kanyicska B, Lerant A, Nagy G. Prolactin: structure, function, and regulation of secretion. Physiol Rev 2000; 80: 1523-1631.

65 Walsh RJ, Slaby FJ, Posner BI. A receptor-mediated mechanism for the transport of prolactin from blood to cerebrospinal fluid. Endocrinology 1987; 120: 1846-1850.

66 Ben-Jonathan N, Hugo ER, Brandebourg TD, LaPensee CR. Focus on prolactin as a metabolic hormone. Trends Endocrinol Metab 2006; 17: 110-116.

67 Byatt JC, Staten NR, Salsgiver WJ, Kostelc JG, Collier RJ. Stimulation of food intake and weight gain in mature female rats by bovine prolactin and bovine growth hormone. Am J Physiol Endocrinol Metab 1993; 264: E986-E992.

68 Gerardo-Gettens T, Moore BJ, Stern JS, Horwitz BA. Prolactin stimulates food intake in a dose-dependent manner. Am J Physiol Regul Integr Comp Physiol 1989; 256: R276-R280.

69 Freemark M, Fleenor D, Driscoll P, Binart N, Kelly PA. Body weight and fat deposition in prolactin receptor-deficient mice. Endocrinology 2001; 142: 532-537.

70 Kelly MA, Rubinstein M, Asa SL, Zhang G, Saez C, Bunzow JR, Allen RG, Hnasko R, Ben-Jonathan N, Grandy DK, Low MJ. Pituitary lactotroph hyperplasia and chronic hyperprolactinemia in dopamine D2 receptor-deficient mice. Neuron 1997; 19: 103-113.

71 Cristina C, Díaz-Torga G, Baldi A, Góngora A, Rubinstein M, Low MJ, Becú-Villalobos D. Increased pituitary vascular endothelial growth factor-A in dopaminergic D2 receptor knockout female mice. Endocrinology 2005; 146: 2952-2962.

72 García-Tornadú I, Díaz-Torga G, Risso GS, Silveyra P, Cataldi N, Ramirez MC, Low MJ, Libertun C, Becu-Villalobos D. Hypothalamic orexin, OX1, aMSH, NPY and MCRs expression in dopaminergic D2R knockout mice. Neuropeptides 2009; 43: 267-274.

73 Bello EP, Mateo Y, Gelman DM, Noaín D, Shin JH, Low MJ, Alvarez VA, Lovinger DM, Rubinstein M. Cocaine supersensitivity and enhanced motivation for reward in mice lacking dopamine D2 autoreceptors. Nat Neurosci 2011; 14: 1033-1038.

74 Johnson PM, Kenny PJ. Dopamine D2 receptors in addiction-like reward dysfunction and compulsive eating in obese rats. Nat Neurosci 2010; 13: 635-641. 
75 García-Tornadu I, Risso G, Perez-Millan MI, Noain D, Diaz-Torga G, Low MJ, Rubinstein M, Becu-Villalobos D. Neurotransmitter modulation of the GHRH-GH axis. In: Arzt E, Bronstein M, Guitelman M, eds. Frontiers of Hormone Research. Basel: Karger, 2010; 59-69.

76 Perez Millan MI, Luque GM, Ramirez MC, Noain D, Ornstein AM, Rubinstein $M$, Becu-Villalobos D. Selective disruption of dopamine D2 receptors in pituitary lactotropes increases body weight and adiposity in female mice. Endocrinology 2013; 155: 829-839.

77 Noaín D, Pérez-Millán MI, Bello EP, Luque GM, Cordero RC, Gelman DM, Peper M, Tornadu IG, Low MJ, Becú-Villalobos D, Rubinstein M. Central dopamine D2 receptors regulate growth-hormone-dependent body growth and pheromone signaling to conspecific males. J Neurosci 2013; 33: 5834-5842.

78 Augustine RA, Ladyman SR, Grattan DR. From feeding one to feeding many: hormone-induced changes in bodyweight homeostasis during pregnancy. J Physiol 2008; 586: 387-397.

79 Fleenor D, Arumugam R, Freemark M. Growth hormone and prolactin receptors in adipogenesis: STAT-5 activation, suppressors of cytokine signaling, and regulation of insulin-like growth factor I. Horm Res 2006; 66: 101-110.

80 Brandebourg TD, Bown JL, Ben-Jonathan N. Prolactin upregulates its receptors and inhibits lipolysis and leptin release in male rat adipose tissue. Biochem Biophys Res Commun 2007; 357: 408-413.

81 Chehab FF, Lim ME, Lu R. Correction of the sterility defect in homozygous obese female mice by treatment with the human recombinant leptin. Nat Genet 1996; 12: 318-320.

82 Barash IA, Cheung CC, Weigle DS, Ren H, Kabigting EB, Kuijper JL, Clifton DK, Steiner RA. Leptin is a metabolic signal to the reproductive system. Endocrinology 1996; 137: 3144-3147.

83 Lee G-H, Proenca R, Montez JM, Carroll KM, Darvishzadeh JG, Lee JI, Friedman JM. Abnormal splicing of the leptin receptor in diabetic mice. Nature 1996; 379: 632-635.

84 Yamaoka K, Saharinen P, Pesu M, Holt VE, Silvennoinen 0, O'Shea JJ. The Janus kinases (Jaks). Genome Biol 2004; 5: 253.

85 Myers MG. Leptin receptor signaling and the regulation of mammalian physiology. Recent Prog Horm Res 2004; 59: 287-304.

86 Bjørbæk C, Uotani S, da Silva B, Flier JS. Divergent signaling capacities of the long and short isoforms of the leptin receptor. J Biol Chem 1997; 272: 32686-32695.

87 Clément K, Vaisse C, Lahlou N, Cabrol S, Pelloux V, Cassuto D, Gourmelen $M$, Dina $C$, Chambaz J, Lacorte JM, Basdevant $A$, Bougnères $P$, Lebouc $Y$, Froguel $P$, Guy-Grand B. A mutation in the human leptin receptor gene causes obesity and pituitary dysfunction. Nature 1998; 392: 398-401.

88 Bates SH, Stearns WH, Dundon TA, Schubert M, Tso AWK, Wang $Y$, Banks AS, Lavery HJ, Haq AK, Maratos-Flier E, Neel BG, Schwartz MW, Myers MG Jr. STAT3 signalling is required for leptin regulation of energy balance but not reproduction. Nature 2003; 421: 856-859.

89 Boulton TG, Zhong Z, Wen Z, Darnell JE, Stahl N, Yancopoulos GD. STAT3 activation by cytokines utilizing gp130 and related transducers involves a secondary modification requiring an $\mathrm{H} 7$-sensitive kinase. Proc Natl Acad Sci USA 1995; 92: 6915-6919.

90 Gao O, Mezei G, Nie Y, Rao Y, Choi CS, Bechmann I, Leranth C, ToranAllerand D, Priest CA, Roberts JL, Gao XB, Mobbs C, Shulman GI, Diano $S$, Horvath TL. Anorectic estrogen mimics leptin's effect on the rewiring of melanocortin cells and Stat3 signaling in obese animals. Nat Med 2007; 13: 89-94.

91 Zhao AZ, Huan J-N, Gupta S, Pal R, Sahu A. A phosphatidylinositol 3kinase-phosphodiesterase 3B-cyclic AMP pathway in hypothalamic action of leptin on feeding. Nat Neurosci 2002; 5: 727-728.
92 Niswender KD, Morton GJ, Stearns WH, Rhodes CJ, Myers MG, Schwartz MW. Intracellular signalling: key enzyme in leptin-induced anorexia. Nature 2001; 413: 794-795.

93 Xu AW, Kaelin CB, Takeda K, Akira S, Schwartz MW, Barsh GS. PI3K integrates the action of insulin and leptin on hypothalamic neurons. J Clin Invest 2005; 115: 951-958.

94 Allison MB, Myers MG. 20 YEARS OF LEPTIN: connecting leptin signaling to biological function. J Endocrinol 2014; 223: T25-T35.

95 Spanswick D, Smith MA, Mirshamsi S, Routh VH, Ashford ML. Insulin activates ATP-sensitive $\mathrm{K}^{+}$channels in hypothalamic neurons of lean, but not obese rats. Nat Neurosci 2000; 3: 757-758.

96 Patterson CM, Villanueva EC, Greenwald-Yarnell M, Rajala M, Gonzalez IE, Saini N, Jones J, Myers MG Jr. Leptin action via LepR-b Tyr 1077 contributes to the control of energy balance and female reproduction. $\mathrm{Mol}$ Metab 2012; 1: 61-69.

97 Singireddy AV, Inglis MA, Zuure WA, Kim JS, Anderson GM. Neither signal transducer and activator of transcription 3 (STAT3) or STAT5 signaling pathways are required for leptin's effects on fertility in mice. Endocrinology 2013; 154: 2434-2445.

98 Björnholm M, Münzberg $H$, Leshan RL, Villanueva EC, Bates SH, Louis GW, Jones JC, Ishida-Takahashi R, Bjørbaek C, Myers MG Jr. Mice lacking inhibitory leptin receptor signals are lean with normal endocrine function. J Clin Invest 2007; 117: 1354-1360.

99 Burgos-Ramos E, Chowen JA, Arilla-Ferreiro E, Canelles S, Argente J, Barrios V. Chronic central leptin infusion modifies the response to acute central insulin injection by reducing the interaction of the insulin receptor with IRS2 and increasing its association with SOCS3. J Neurochem 2011; 117: 175-185.

100 White MF. IRS proteins and the common path to diabetes. Am J Physiol Endocrinol Metab 2002; 283: E413-E422.

101 Pardini AW, Nguyen HT, Figlewicz DP, Baskin DG, Williams DL, Kim F, Schwartz MW. Distribution of insulin receptor substrate-2 in brain areas involved in energy homeostasis. Brain Res 2006; 1112: 169178.

102 Burks DJ, de Mora JF, Schubert M, Withers DJ, Myers MG, Towery HH, Altamuro SL, Flint CL, White MF. IRS-2 pathways integrate female reproduction and energy homeostasis. Nature 2000; 407: 377-382.

103 Sadagurski M, Leshan RL, Patterson C, Rozzo A, Kuznetsova A, Skorupski J, Jones JC, Depinho RA, Myers MG Jr, White MF. IRS2 signaling in LepR-b neurons suppresses Fox01 to control energy balance independently of leptin action. Cell Metab 2012; 15: 703-712.

104 Cantley LC. The phosphoinositide 3-kinase pathway. Science 2002; 296: 1655-1657.

105 Vanhaesebroeck B, Ali K, Bilancio A, Geering B, Foukas LC. Signalling by PI3K isoforms: insights from gene-targeted mice. Trends Biochem Sci 2005; 30: 194-204.

106 Hörsch D, Kahn CR. Region-specific mRNA expression of phosphatidylinositol 3-kinase regulatory isoforms in the central nervous system of C57BL/6J mice. J Comp Neurol 1999; 415: 105-120.

107 Bi L, Okabe I, Bernard DJ, Nussbaum RL. Early embryonic lethality in mice deficient in the p110beta catalytic subunit of PI 3-kinase. Mamm Genome Off J Int Mamm Genome Soc 2002; 13: 169-172.

108 Al-Qassab H, Smith MA, Irvine EE, Guillermet-Guibert J, Claret M, Choudhury Al, Selman C, Piipari K, Clements M, Lingard S, Chandarana K, Bell JD, Barsh GS, Smith AJ, Batterham RL, Ashford ML, Vanhaesebroeck $B$, Withers DJ. Dominant role of the $p 110 \beta$ isoform of PI3K over p110 $\alpha$ in energy homeostasis regulation by POMC and AgRP neurons. Cell Metab 2009; 10: 343-354.

109 Geer EB, Shen W. Gender differences in insulin resistance, body composition, and energy balance. Gend Med 2009; 6(Suppl 1): 60-75. 
110 Roth SM, Ferrell RE, Peters DG, Metter EJ, Hurley BF, Rogers MA. Influence of age, sex, and strength training on human muscle gene expression determined by microarray. Physiol Genomics 2002; 10: 181-190.

111 Paula FJ, Pimenta WP, Saad MJ, Paccola GM, Piccinato CE, Foss MC. Sex-related differences in peripheral glucose metabolism in normal subjects. Diabète Métabolisme 1990; 16: 234-239.

112 Arciero PJ, Goran MI, Poehlman ET. Resting metabolic rate is lower in women than in men. J Appl Physiol 1993; 75: 2514-2520.

113 Uranga AP, Levine J, Jensen M. Isotope tracer measures of meal fatty acid metabolism: reproducibility and effects of the menstrual cycle. Am J Physiol Endocrinol Metab 2005; 288: E547-E555.

114 De Maddalena C, Vodo S, Petroni A, Aloisi AM. Impact of testosterone on body fat composition. J Cell Physiol 2012; 227: 3744-3748.

115 Corona G, Monami M, Rastrelli G, Aversa A, Sforza A, Lenzi A, Forti G, Mannucci E, Maggi M. Type 2 diabetes mellitus and testosterone: a meta-analysis study. Int J Androl 2011; 34: 528-540.

116 Escobar-Morreale HF, Álvarez-Blasco F, Botella-Carretero Jl, LuqueRamírez M. The striking similarities in the metabolic associations of female androgen excess and male androgen deficiency. Hum Reprod 2014; 29: 2083-2091.

117 Pitteloud N, Mootha VK, Dwyer AA, Hardin M, Lee H, Eriksson K-F, Tripathy D, Yialamas M, Groop L, Elahi D, Hayes FJ. Relationship between testosterone levels, insulin sensitivity, and mitochondrial function in men. Diabetes Care 2005; 28: 1636-1642.

118 Law J, Bloor I, Budge H, Symonds ME. The influence of sex steroids on adipose tissue growth and function. Horm Mol Biol Clin Investig 2014; 19: 13-24.

119 Lund TD, Munson DJ, Haldy ME, Handa RJ. Dihydrotestosterone may inhibit hypothalamo-pituitary-adrenal activity by acting through estrogen receptor in the male mouse. Neurosci Lett 2004; 365: 43-47.

120 Sato T, Matsumoto T, Yamada T, Watanabe T, Kawano H, Kato S. Late onset of obesity in male androgen receptor-deficient (AR KO) mice. Biochem Biophys Res Commun 2003; 300: 167-171.

121 Fan W, Yanase T, Nishi Y, Chiba S, Okabe T, Nomura M, Yoshimatsu H, Kato $\mathrm{S}$, Takayanagi $\mathrm{R}$, Nawata H. Functional potentiation of leptin-signal transducer and activator of transcription 3 signaling by the androgen receptor. Endocrinology 2008; 149: 6028-6036.

122 Yu I-C, Lin H-Y, Liu N-C, Sparks JD, Yeh S, Fang L-Y, Chen L, Chang C. Neuronal androgen receptor regulates insulin sensitivity via suppression of hypothalamic NF- $\kappa$ B-mediated PTP1B expression. Diabetes 2013; 62: 411423.

123 Nohara K, Laque A, Allard C, Münzberg H, Mauvais-Jarvis F. Central mechanisms of adiposity in adult female mice with androgen excess. Obesity 2014; 22: 1477-1484.

124 Lovejoy JC, Champagne CM, de Jonge L, Xie H, Smith SR. Increased visceral fat and decreased energy expenditure during the menopausal transition. Int J Obes 2008; 32: 949-958.
125 Maliqueo $M$, Sun $M$, Johansson J, Benrick $A$, Labrie $F$, Svensson $H$, Lönn $\mathrm{M}$, Duleba AJ, Stener-Victorin E. Continuous administration of a P450 aromatase inhibitor induces polycystic ovary syndrome with a metabolic and endocrine phenotype in female rats at adult age. Endocrinology 2012; 154: 434-445.

126 Simpson ER, Jones ME. Of mice and men: the many guises of estrogens. Ernst Schering Found Symp Proc 2006; 1: 45-67.

127 Heine PA, Taylor JA, Iwamoto GA, Lubahn DB, Cooke PS. Increased adipose tissue in male and female estrogen receptor- $\alpha$ knockout mice. Proc Natl Acad Sci USA 2000; 97: 12729-12734.

128 Roesch DM. Effects of selective estrogen receptor agonists on food intake and body weight gain in rats. Physiol Behav 2006; 87: 3944.

129 Yepuru M, Eswaraka J, Kearbey JD, Barrett CM, Raghow S, Veverka KA, Miller DD, Dalton JT, Narayanan R. Estrogen receptor- $\beta$-selective ligands alleviate high-fat diet- and ovariectomy-induced obesity in mice. J Biol Chem 2010; 285: 31292-31303.

130 Foryst-Ludwig A, Clemenz M, Hohmann S, Hartge M, Sprang C, Frost N, Krikov M, Bhanot S, Barros R, Morani A, Gustafsson J, Unger T, Kintscher $U$. Metabolic actions of estrogen receptor beta $(E R \beta)$ are mediated by a negative cross-talk with PPAR $\gamma$. PLoS Genet 2008; 4: e1000108.

131 Barros RPA, Machado UF, Warner M, Gustafsson J-Å. Muscle GLUT4 regulation by estrogen receptors ER $\beta$ and ER $\alpha$. Proc Natl Acad Sci USA 2006; 103: 1605-1608.

132 Brock 0, De Mees C, Bakker J. Hypothalamic expression of oestrogen receptor $\alpha$ and androgen receptor is sex-, age- and region-dependent in mice. $J$ Neuroendocrinol 2015; 27: 264-276.

133 XU Y, Nedungadi TP, Zhu L, Sobhani N, Irani BG, Davis KE, Zhang $X$, Zou F, Gent LM, Hahner LD, Khan SA, Elias CF, Elmquist JK, Clegg DJ. Distinct hypothalamic neurons mediate estrogenic effects on energy homeostasis and reproduction. Cell Metab 2011; 14: 453-465.

134 Asarian L, Geary N. Cyclic estradiol treatment normalizes body weight and restores physiological patterns of spontaneous feeding and sexual receptivity in ovariectomized rats. Horm Behav 2002; 42: 461-471.

135 Musatov S, Chen W, Pfaff DW, Mobbs CV, Yang X-J, Clegg DJ, Kaplitt $M G$, Ogawa $S$. Silencing of estrogen receptor $\alpha$ in the ventromedial nucleus of hypothalamus leads to metabolic syndrome. Proc Natl Acad Sci USA 2007; 104: 2501-2506.

136 Sharma G, Hu C, Brigman JL, Zhu G, Hathaway HJ, Prossnitz ER. GPER deficiency in male mice results in insulin resistance, dyslipidemia, and a proinflammatory state. Endocrinology 2013; 154: 4136-4145.

137 Park CJ, Zhao Z, Glidewell-Kenney C, Lazic M, Chambon P, Krust A, Weiss J, Clegg DJ, Dunaif A, Jameson JL, Levine JE. Genetic rescue of nonclassical $E R \alpha$ signaling normalizes energy balance in obese Er $\alpha$-null mutant mice. J Clin Invest 2011; 121: 604-612. 